\author{
А.М. Молдован \\ Институт русского языка им. В. В. Виноградова РАН \\ (Москва, Россия) \\ alexandr.moldovan@gmail.com
}

\title{
ВАРИАТИВНОСТЬ СВЯЗКИ 1 Л. МН. Ч. В ДРЕВНЕРУССКОЙ ПИСЬМЕННОСТИ
}

Фиксируемая в древнерусских памятниках XI-XVII вв. широкая вариативность написаний бытийной связки настоящего времени 1 л. мн. ч. (ксмъ, ксмы, ксмь, ксмн, єсмо, ксма, ксме, ксма) определялась разнообразными факторами, действовавшими на разных этапах истории русской письменности. Материалы корпусов древнерусских и старорусских текстов позволяют изучать условия и закономерности действия этих факторов. Особый интерес представляет форма есмя, отсутствующая в других славянских языках, которая получила широкое распространение в русской деловой письменности и гибридных разновидностях книжного языка XIV-XVII вв. В статье обосновывается гипотеза о том, что написание есмя отражает акающее произношение диалектной формы есме. Появившись в зоне аканья, есмя утвердилось в качестве письменной нормы Посольского приказа и потому получило распространение на всей территории Московского государства, включая те области, где аканья не было.

Ключевые слова: древнерусский язык, древнерусская письменность, история русского языка, историческая диалектология.

Презентная глагольная связка в форме 1 л. мн. ч., как известно, отличалась в древнерусском языке широким разнообразием окончаний. Письменные источники XI-XVII вв. фиксируют восемь (!) вариантов окончаний этой формы, в которых представлен почти весь репертуар гласных древнерусского языка: ксмъ, ксмы, ксмь, єсмн, ксмо, ксма, ксмє, ксма. Некоторые сведения об этих написаниях, собранные А.И. Соболевским, обычно приводятся в обзорах по древнерусской грамматике для иллюстрации наиболее заметных изменений форм спряжения, противопоставивших русский язык другим славянским языкам [Соболевский 1907: 161-162; Дурново 2000: 306-307; Кузнецов 1953: 206; Филин 1972: 463-468; Историческая грамматика 1982: 48-49 и др.]. Остаются, однако, в стороне вопросы, существенные для понимания эволюции этих форм, условий и закономерностей их использования. Возможность обращения к современным корпусам древнерусских 
и старорусских текстов ${ }^{1}$ открывает некоторую перспективу в изучении этих аспектов, хотя корпусные данные, к сожалению, еще далеки от необходимой степени полноты и репрезентативности. Кроме того, приходится считаться с тем, что презентные формы связки 1 л. мн. ч. редко встречаются в древних книжных текстах во многих из них, в том числе больших рукописных книгах, отсутствуют контексты, в которых могли бы использоваться конструкции с этой связкой.

Старославянской нормой для глаголов в презенсе 1 мн. было окончание. -мъ (нєсемъ, Хвамнмъ, ксмъ, Аамъ и т. П.) ${ }^{2}$. В некоторыХ памятниках «старославянского канона» у нетематических глаголов 1 мн. отмечается окончание -ы, появление которого объясняется воздействием личного местоимения мы: ксмъ, Адмъ, вЊмъ [Вайан 1952: 250]. Новое окончание позволило различать презентные формы нетематических глаголов 1 ед. и 1 мн., в которых после падения редуцированных совпали конечные -мь и -мъ. Характерно, что эта инновация отмечается в таких рукописях, как Клоцев сборник и Супрасльская рукопись, тогда как в старославянских евангелиях и псалтырях она практически отсутствует (единственное исключение написание - мы вњмы в Зографском евангелии). В Клоцевом сборнике и Супрасльской рукописи окончание -ъ в 1 мн. встречается не только у нетематических, но и у тематических глаголов, при этом не только в презенсе, но и в формах императива, сослагательного наклонения и аориста [Вайан 1952: 250; Селищев II, 1952: 157]: Аа оувЊмы таны (КЛОЦ. сб.), накажемы, нмамы (СУПр.), аор. сьвндоХомы, поманххомы (Супр.) и др. В Изборнике 1073 г. словоформы на -мы представлены 57 примерами, в их числе 53 формы настоящего времени [Ралева 2013: 122]. По мнению авторов академической исторической грамматики древнеболгарского языка, непосредственным источником этой книжной инновации являются древние северовосточные болгарские говоры [Граматика на старобългарския език 1991: 285], хотя презентное окончание 1 мн. -my представлено также в польском языке и лужицких и чешских говорах восточной Моравии [Селищев II, 1952: 157].

Несмотря на то, что связка настоящего времени в древнерусском языке на протяжении XI-XVII вв. постепенно утрачивалась, в формах 1-го и 2 л. она сохранялась в составе именных групп до XVI в. Это значит, что вплоть до этого времени употребление на письме глагольных связочных форм имело соответствие в живом языке писавших, и необходимые для этого орфографические правила усваивались писцами путем их соотнесения с особенностями устного языка.

В ранних памятниках древнерусской книжной письменности XI-XIII вB. в 1 мн. представлены старославянские написания ксмъ, ксмь, ксмыз ${ }^{3}$ (см. таблицу).

${ }^{1}$ В работе использованы материалы древнерусского и старорусского корпусов, входящих в состав Национального корпуса русского языка, а также текстов, доступных на портале «Манускрипт».

2 При этом в болгарских диалектах того времени, несомненно, были и другие формы - прежде всего формы с окончанием -ме, о которых свидетельствуют данные среднеболгарских памятников и современных болгарских говоров [Селищев II, 1952: 156].

3 Здесь и далее в количественных данных учтены написания отрицательных форм нъcмъ, н'ъсмы и т. п. 


\begin{tabular}{|l|c|c|c|}
\hline & ксмъ & ксмь & ксмы \\
\hline Остромирово евангелие 1056-1057 гг. & - & 3 & - \\
\hline Архангельское евангелие 1092 г. & 2 & 1 & - \\
\hline Минея служебная на октябрь 1096 г. & 1 & 2 & - \\
\hline Изборник 1073 г. & 23 & 1 & 5 \\
\hline Изборник 1076 г. & 2 & 1 & - \\
\hline Пандекты Антиоха (ХІ в.) & 57 & 1 & - \\
\hline 13 Слов Григория Богослова (ХІ в.) & 3 & - & 1 \\
\hline Ильина книга (ХІ-ХІІ в.) & 1 & - & - \\
\hline Синайский патерик (ХІ-ХІІ вв.) & 5 & - & - \\
\hline Мстиславово евангелие (ХІ-ХІІ в.) & 5 & - & - \\
\hline Стихирарь по сп. Син. 279, ХІІ в. & - & 2 & - \\
\hline Триодь постная по сп. Син. 319, ХІІ в. & - & 2 & - \\
\hline Триодь цветная по сп. Син. Тип. 138, ХІ/ХІІ в. и ХІІІ в. & 2 & - & - \\
\hline Триодь цветная нотирован. по сп. Воскр. 27, кон. ХІІ в. & 1 & - & - \\
\hline Чудеса Николы (ХІІ в.) & 2 & - & 1 \\
\hline Успенский сборник (ХІІ-ХІІІ вв.) & 24 & - & 5 \\
\hline Троицкий сборник (ХІІ-ХІІІ вв.) & 33 & 1 & 8 \\
\hline Софийский пролог. Синаксарь (ХІІ-ХІІІ в.) & 1 & - & - \\
\hline Захариинский паримейник (1271 г.) & 1 & - & 1 \\
\hline
\end{tabular}

Написание 1 мн. ксмъ сохраняется в древнерусской письменности в качестве нормативного приблизительно до XIII в. В рукописях XIV в. оно встречается уже существенно реже, а в более позднее время практически выходит из употребления.

В то же время, как показывают приведенные данные, орфографическое противопоставление презентных связок 1 ед. и 1 мн. даже в древнюю эпоху не было вполне строгим. В частности, в Остромировом евангелии 1056-1057 гг. написание ксмъ вообще отсутствует, а единая форма ксмь используется и для 1 ед. (78х), и для 1 мн. (3x).

После падения редуцированных и отвердения конечного [м’] в древнерусском языке утратились фонологические условия для орфографического противопоставления 1 ед. ксмь и 1 мн. ксмъ. При отсутствии у писца возможности опереться на произношение этих форм в живом языке увеличивалась вероятность неправильных написаний. Написание ксмь в значении 1 мн. встречается даже в тех рукописях XIII-XV вв., в которых уже отсутствует ксмъ и в основном используется ксмы и другие формы: Новгородская I летопись по Синодальному списку (ксмь 1х, наряду с ксмы 3х и ксмє 6х), Повесть временных лет по Ипатьевскому списку (єсмь 1х, наряду с есмы 11х, нъсмы 2x, есмн 4х и єсмє 2x), Киевская летопись по Ипатьевскому списку (єсмь 7х, наряду с есмы 37х и єсмн $3 \mathrm{x})$, Галицкая летопись (єсмь 1х, єсмы 5х), Волынская летопись (єсмь 1х, єсмы 2x), «Пчела» (єсмь 1х, ксмы 22х) и др. [НКРЯ]. И наоборот, в некоторых других 
рукописях XIV-XV вв. встречается написание ксмъ в значении 1 ед. ${ }^{4}$ Например, в древнейшем списке «Жития Андрея Юродивого» (РГАДА, Син. тип. 182), относящемся к кон. XIV в., и сделанной с него копии XV в. (РНБ, Сол. 216) написание ксмъ 6 раз употреблено в значении 1 ед. (наряду с ксмь 70х) и только 3 раза - в старом значении 1 мн. (наряду с более частотным ксмь - $12 \mathrm{x}$, ксмы - 4x, ксме - 3x):

\begin{tabular}{|c|c|c|c|c|c|}
\hline \multicolumn{2}{|c|}{ ІссMZ } & \multicolumn{2}{|c|}{ КсMь } & \multirow{2}{*}{ ксмы } & \multirow{2}{*}{ КСME } \\
\hline 1 ед. & 1 мн. & 1 ед. & $1 \mathrm{мн}$ & & \\
\hline 6 & 3 & 70 & 12 & 4 & 3 \\
\hline
\end{tabular}

Большое количество написаний ксмъ (с орфографическим вариантом ксмо) в значении 1 ед. содержится в новгородских берестяных грамотах [ДНД: 714-715]. Тем не менее в большинстве рукописей противопоставление написаний 1 мн. ксмъ и 1 ед. ксмь сохраняется в списках приблизительно до рубежа XII-XIII вв.

C середины XIV в. в небогослужебных текстах в форме 1 мн. спорадически встречается написание єсмн, которое в качестве диалектного варианта єсмь в основном было связкой 1 ед. Древнейший пример употребления єсмн в значении 1 мн. (наряду с єсмы) обнаруживается в Послании Василия Калики Феодору Тверскому о рае (1347):

Тъмь, еже изысках, и се пишу к тебъ, понеже, брате, по Божию повельнию, должъни есми другъ къ другу посланиа творити о исправленыхъ намъ Божественых писаний отъ святых апостоль и великих святитель, якоже бо ть святии апостоли бес престаниа посланиа творяху другъ къ другу, такоже и намъ подобно есть, в нихъ бо мъсто поставлени есмы [НКРЯ].

Исключительно в значении 1 мн. єсмн используется в «Задонщине» (4x): есми были, правнуки есми, сами себђ есми два брата, есми ... добыли.

Смешение 1 ед. и 1 мн. в употреблении формы єсмь и єсмн часто встречается в летописях:

\begin{tabular}{|l|c|c|c|c|c|c|}
\hline & \multicolumn{2}{|c|}{ єсмь } & \multicolumn{2}{|c|}{ єсмн } & \multirow{2}{*}{ єсмы } & \multirow{2}{*}{ єсмє } \\
\cline { 2 - 8 } & $\mathbf{1}$ ед. & $\mathbf{1}$ мн. & $\mathbf{1}$ ед. & $\mathbf{1}$ мн. & & \\
\hline Повесть временных лет (Ипат.) & $20 \mathrm{x}$ & $1 \mathrm{x}$ & - & $4 \mathrm{x}$ & $13 \mathrm{x}$ & $2 \mathrm{x}$ \\
\hline Киевская летопись (Ипат.) & $96 \mathrm{x}$ & $7 \mathrm{x}$ & $12 \mathrm{x}$ & $3 \mathrm{x}$ & $37 \mathrm{x}$ & $10 \mathrm{x}$ \\
\hline $\begin{array}{l}\text { Новгородская Карамзинская летопись, 2-я выборка } \\
\text { (до 1428 г.) }\end{array}$ & $14 \mathrm{x}$ & - & $2 \mathrm{x}$ & $1 \mathrm{x}$ & - & $1 \mathrm{x}$ \\
\hline Псковская 3-я летопись, Строевский список (1400-1568) & $5 \mathrm{x}$ & - & $2 \mathrm{x}$ & $1 \mathrm{x}$ & $1 \mathrm{x}$ & $1 \mathrm{x}$ \\
\hline
\end{tabular}

Очень часто форма есми используется в значении 1 мн. в Сербской «Александрии» (русский список XV в.): из 35 примеров употребления формы есми 21 пример - 1 ед., а $14-1$ мн. (умерли есми, доволни... есми, разорили есми, прияли есми (5x), водимы есми, дошли есми, видели есми и т. п.).

${ }^{4}$ По мнению авторов академической «Исторической грамматики», такие написания в списках XII-XV вв. отражают «или отвердение согласного [м'] после утраты конечного редуцированного 
Столь большое количество примеров девиантного употребления форм єсмь и єсми в значении 1 мн. не может быть объяснено только ошибками или описками писцов, а, по-видимому, свидетельствуют о сближении форм 1 мн. и 1 ед. у этого глагола 5 .

С другой стороны, разнообразные коммуникативные ситуации требовали однозначного указания на агенса (прежде всего в деловых документах). Поэтому необходимость в формальном противопоставлении презенсных связок 1 мн. и 1 ед. все же должна была сохраняться. Выражением этой необходимости стало постепенное увеличение в русской книжной традиции числа написаний 1 мн. ксмы. Эта форма не засвидетельствована в современных русских говорах, и нет данных о том, чтобы эта книжная инновация имела какое-то соответствие в живой древнерусской речи 6 . Но древнерусские книжники, издавна встречавшие в староболгарских источниках написание ксмы, несомненно, улавливали его связь с личным местоимением мы и не могли не видеть в этом его очевидного преимущества перед написаниями ксмъ и ксмь. C XIV в. у некоторых писцов написание 1 мн. ксмы фиксируется в качестве новой нормы. Например, в Лаврентьевской летописи 1377 г. наблюдается четкое распределение форм 1 ед. ксмъ (26x) и 1 мн. ксмы (30x). Но в целом экспансия написаний єсмы при копировании древнерусских рукописей происходила не быстро. В 16-ти Словах Григория Богослова с Толкованиями Никиты Ираклийского по рукописи XIV в. (ГИМ, Син. 43), полностью написанной одним писцом, в тексте Слов Григория в значении 1 мн. используются только ксмъ (4х) и ксмь (7x), при этом отсутствует форма ксмы ${ }^{7}$. А инкорпорированные в текст этих Слов и переписанные тем же писцом Толкования Никиты Ираклийского в 1 мн. содержат существенно меньше написаний с -мъ и -мь (ксмъ 1 , ксмь $4 \mathrm{x}$ ); в основном в них используется ксмы $(29 \mathrm{x})$, которое, следовательно, должно быть отнесено к орфографии антиграфа этой рукописи, а возможно, и к архетипу славянского перевода Толкований (1-я пол. XII в.). Между прочим, этот пример демонстрирует различие в орфографических стратегиях, с одной стороны, простых переписчиков, нередко сохранявших написания более древних антиграфов, а с другой - авторов оригинальных текстов и переводов, более последовательно отражавших в своей работе языковые инновации.

переднего образования, или неразвития мягкости губного перед [ь] в эпоху смягчения полумягких, в силу чего после утраты [ь] на конце слова автоматически появился твердый [м]» [Историческая грамматика 1982: 48].

${ }^{5} \mathrm{Cp}$. аналогичное замечание А.А. Зализняка относительно трех примеров употребления гсми в значении 1 мн. в новгородских берестяных грамотах №370 (2х) и № 20 [ДНД: 139].

${ }^{6}$ Написание єсмы встречается только в двух берестяных грамотах XII века - № 872 и Город. 1. Первая из них происходит с востока Новгородской земли, а вторая ориентирована на наддиалектные нормы [ДНД: 139].

7 Интересно, что даже в том месте текста, где древнейший список 13 Слов Григория Богослова (XI в.) содержит единственное написание єсмы (л. 1в), в этой рукописи XIV в. ему соответствует написание ксмь (л. 39a). 
Начиная с XV в. єсмы становится основной формой 1 мн. в церковнославянских текстах и сохраняет этот статус на протяжении всей дальнейшей истории церковнославянского языка вплоть до новейшего времени.

Изменение письменной нормы употребления связки 1 мн., постепенно сдвигавшейся от єсмъ к єсмы, затронуло прежде всего канонические церковнославянские тексты и отчасти - ориентированные на них гибридные по языку древнерусские переводные и оригинальные произведения.

Традиции деловой и бытовой письменности формировали свои нормы, которые в гораздо большей степени определялись диалектными особенностями языка писавших. Так, в бытовых памятниках древненовгородского ареала для презентной связки 1 мн. издавна использовалось ксмє ${ }^{8}$, противопоставленное 1 ед. ксмь (вар. ксмн). Эта диалектная норма фиксируется в новгородских берестяных грамотах

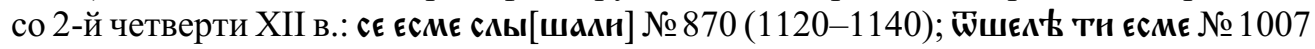
(1140-1155); ЗаБЫМН ЕСМЕ ГЮрЬГЕВН №854 (1140-1160); (СТ)[ОрОВН] ТН ЕСМЕ ВОХЕ

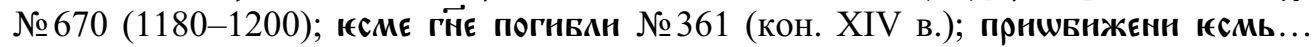
а самн ксмь... № 248 (60-е — 90-е гг. XIV в.); пошАн есме №929 (1430-1450) и др. [ДНД: 715], а также в некоторых пергаменных грамотах - грамоте рижан в Витебск ок. 1300 г., грамоте Витовта 1399 г. и др. [Соболевский 1907: 161]. Использование ксмє в бытовой сфере оказывало заметное влияние и на книжную новгородско-псковскую традицию, где ксмє встречается с ХІІІ в.: в Лобковском Прологе 1262 г. (10x), Псковском апостоле 1307 г. [Соболевский 1907: 161-162], Новгородской I летописи по Синодальному списку (6x, наряду с ксмы 3х и ксмь 1х) и др. В книжных текстах форма ксмє чаще всего используется в составе прямой речи светских лиц; хотя строгого функционального распределения написаний ксмє vs ксмы не наблюдается. Например, имеющиеся в Повести временных лет по Ипатьевскому списку примеры употребления ксмє $(2 \mathrm{x})$ содержатся в составе авторской

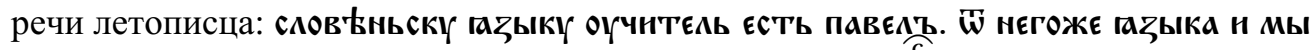

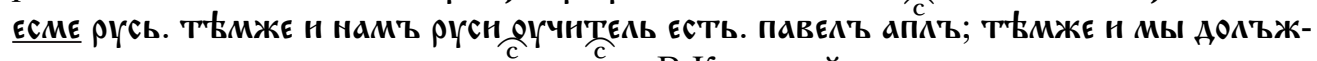

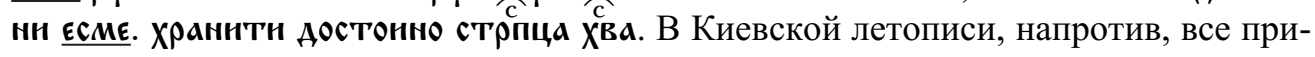
меры употребления єсмє (10x) содержатся исключительно в составе прямой речи светских персонажей. Правда, в Киевской летописи и другие формы 1 мн. также встречаются преимущественно в прямой речи светских лиц: все примеры употребления 1 мн. єсмь (7x) и єсмн (3x), а также преобладающая часть примеров употребления єсмы (37x). Некоторое количество примеров употребления 1 мн. ксмє встречается в «Житии Андрея Юродивого» (3x), «Житии Василия Нового» (1х), Псковской 1-й летописи по Погодинскому списку (1х), Псковской 2-й летописи (2x), Псковской 3-й летописи по Строевскому списку (1х) и других летописях, грамотах, повестях и «словах» и т. п. В Старорусском подкорпусе НКРЯ зафиксировано 39 примеров использования ксмє в 17 документах различных жанров (правовые

8 Формы на -ме имеются также в средне- и новоболгарском, чешском и словацком языках и в закарпатских украинских говорах. По мнению Ф. Кортланда, гласная в окончании 1 мн. есме была взята из окончания 2 мн. -me (ecme), чтобы избежать омонимии окончаний 1 ед. и 1 мн. [Kortland 1979: 63]. 
документы, летописи, повести, «слова» и др.). Больше всего примеров - $16-$ содержится в Новгородской V летописи (1550 г.). А.И. Соболевский обнаружил нЊсмє в евангелии 1358 г., написанном в Московской области [Соболевский 1907: 161], однако в основном употребление ксмє не выходит за пределы новгородскопсковского региона и даже в этих границах не было книжной нормой.

Иную судьбу имела диалектная форма 1 мн. єсма, получившая в русской деловой письменности и гибридных разновидностях книжного языка широкое распространение и ставшая ярким маркером русского письма XIV-XVII вв. В других славянских языках эта форма отсутствует.

Наиболее ранние написания єсма встречаются в договорной грамоте Новгорода с Любеком и Готландом о пограбленном разбойниками товаре $(1373 \text { г. })^{9}$. В этой небольшой грамоте есмя представлено пятью примерами, это явно свидетельствует о нормативности его написания:

От архиепископа новгородьского владыкы Олексњя, от посадника Юргя, от тысячкого Матфъя, от всего Новагорода о той жалобъ, что у насъ быль на любцянъ и на годьцкъ бережанъ. Что взяль у насъ товаръ передъ Невою розбоиникы, тои товаръ твориль есмя въ ихъ городъхъ. Тако и тыи товаръ, что у Стеколмъ взяль, такоже есмя твориль во ихъ городъхъ, в Любкъ да у Гочкого берега. То есмя с ними доконцяль с ними правдою, какъми и наши: с тыхъ есмя спустиль на зень, что ни в которое веремя не поминать. То есмя доконцялъ с посломъ съ Яковомъ и съ Иваномъ из Любка, да съ Григорьею да съ Иваномъ из Гоцкого берега. На томь Яковъ да Иванъ из Любка, да Григоръи да Иванъ из Гоцкого берега хрьстъ цъловаль про тыи товаръ, безъ хытрости [ГВНП, №45].

K концу XIV в. можно отнести употребление есмА в грамоте о «докончании» Дмитрия Донского с Олегом рязанским 1382 г., сохранившейся в копии 14011402 гг. и во множестве более поздних копий: єсмА цєловахн кртъ [Дух. и дог. гр. 1950: 30]. C XV в. число примеров употребления есмА возрастает: оно встречается в грамоте новгородского посадника Александра Фоминича в Ригу, ок. 1400 г. (послали есмх к вамъ бориса кижанинова про его обиду) [Хрест. 1: 144]; грамоте Великого Новгорода Риге с требованием суда над Иньцей Зашембакой (Гинце Сассенбеке) и его братом Артемием (Гертеке), орденским переводчиком, по жалобе новгородца Александра Трифонова сына в неуплате 50 рублей, 1418-1421 гг. (А послали есмя к вамъ сю грамоту съ Олексъемъ с поповичемъ) [ГВНП, № 58];

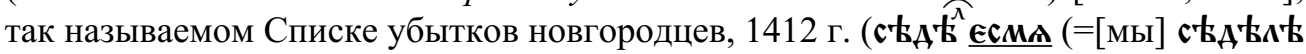

9 Написание єсмх встречается под 1279 г. в Волынской летописи по Ипатьевскому списку:

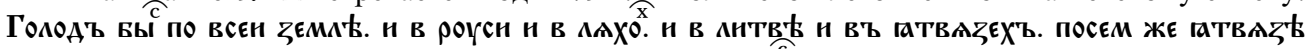

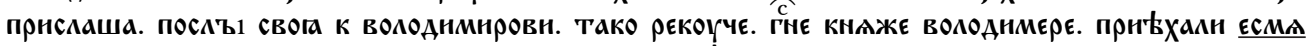

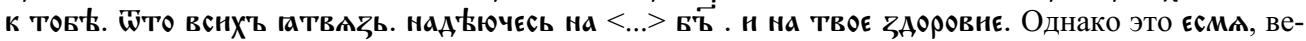
роятней всего, принадлежит писцу Ипатьевского списка, датируемого 1420-ми гг., а не архетипу сообщения, т. к. в Хлебниковском и Погодинском списках ему соответствует єсмы: прієХалн єсмы К ТєБ' [ПСРЛ II: 879]. 
єсма - А.М.) [ДНД: 687] и др. В Старорусском подкорпусе НКРЯ есмя представлено 1755 примерами в 532 документах XV-XVII вв. Почти все они связаны с территориями среднерусских акающих говоров - псковских, тверских, московских и рязанских. Наибольшее количество - 640 примеров - содержат разнообразные грамоты, монастырские записи, посольские отчеты и другие официальные документы. В частности, впечатляющую статистику дает употребление есмя в посольских книгах. Так, в Посольской книге по связям Московского государства с Ногайской Ордой в 1 мн. используется исключительно есмя: в 4-й книге (15511556 гг.) оно употреблено 275 раз, а в 5-й (1557-1561 гг.) - 151 раз. Среди примеров преобладают конструкции с -л-причастием, и в подавляющем числе случаев есмя находится в контактной постпозиции к -л-причастию - 518 примеров. Наиболее частотным является словосочетание дали есмя, представленное более чем в 200 примерах. Кроме того, в этой конструкции используются л-словоформы купили, вельли, взяли, мънили, промьнили, мъняли, выльнили, выльняли, запечатали, кончяли, дълали, розъехали, пожаловали и др.

Обращает на себя внимание четкое распределение в посольских книгах форм 1 ед. есми и 1 мн. есмя:

\begin{tabular}{|l|c|c|}
\hline & $\begin{array}{l}\text { 1 ed. } \\
\text { eсми }\end{array}$ & $\begin{array}{c}1 \text { мн. } \\
\text { eсмя }\end{array}$ \\
\hline Посольская книга по связям Моск. гос-ва с Ногайской Ордой. Кн. 4-я. 1551-1556 гг. & $202 \mathrm{x}$ & $275 \mathrm{x}$ \\
\hline Посольская книга по связям Моск. гос-ва с Ногайской Ордой. Кн. 5-я. 1557-1561 гг. & $157 \mathrm{x}$ & $151 \mathrm{x}$ \\
\hline
\end{tabular}

По-видимому, практика деловой письменности, санкционировавшая употребление диалектной формы есмя, способствовала тому, что ее использование приобрело более широкое нормативное значение. С XV в. есмя распространяется в летописных текстах: Новгородской Карамзинской летописи (8x); Псковской 1 летописи по Тихановскому списку (2x) и по Погодинскому списку (4x); Псковской 3 летописи по Архивскому (1х) и Строевскому (1х) спискам и др. Особенно часто написание есмя используют Никоновская летопись и Московский летописный свод:

\begin{tabular}{|l|c|c|}
\hline & есмь & есмя \\
\hline Никоновская летопись (859-1176 гг.) & $12 \mathrm{x}$ & $10 \mathrm{x}$ \\
\hline Никоновская летопись (1176-1362 гг.) & $2 \mathrm{x}$ & $23 \mathrm{x}$ \\
\hline Никоновская летопись (1362-1424 гг.) & $13 \mathrm{x}$ & $19 \mathrm{x}$ \\
\hline Никоновская летопись (1425-1506 гг.) & $15 \mathrm{x}$ & $13 \mathrm{x}$ \\
\hline Моск. летописный свод (1560-1570) & $61 \mathrm{x}$ & $18 \mathrm{x}$ \\
\hline
\end{tabular}

Среди художественных текстов XV-XVI вв., в которых употребляется есмя,такие известные произведения, как «Задонщина» (3x, наряду с есми 4x), «Сказание о Мамаевом побоище» (5x, наряду с есмы 2х и есми 1х); «Сказание о князьях Владимирских» (1x, наряду с есмо $1 \mathrm{x})$, «Хождение на Флорентийский собор» (6x, наряду с есмы 1х и есми 3x) и др.; сочинения известных авторов: Афанасия 
Никитина, Нила Сорского, Геннадия Гонзова, Иосифа Волоцкого, Ивана Грозного, Андрея Курбского, Арсения Суханова и др. У Ивана Грозного встречаются четыре формы 1 мн. - есмы, есми, есмо и есмя, распределенных стилистически. При этом есмя значительно преобладает:

\begin{tabular}{|l|c|c|c|c|}
\hline & есмы & есми & есмо & есмя \\
\hline 1-е послание Курбскому (1564) & - & 3 & - & 11 \\
\hline 2-е послание Курбскому (1577) & 1 & - & - & - \\
\hline Послание в Кир.-Белоз. монастырь (1573) & - & - & - & 7 \\
\hline Ответ Яну Роките (1570) & 2 & 2 & - & 1 \\
\hline Послание Стефану Баторию (1579) & - & - & 4 & 3 \\
\hline Послание Стефану Баторию (1581) & - & - & - & 19 \\
\hline Послание английской королеве Елизавете I (1570) & - & - & - & 18 \\
\hline Послание шведскому королю Юхану ІІІ (1572) & - & - & - & 5 \\
\hline Послание шведскому королю Юхану ІІІ (1573) & - & - & - & 10 \\
\hline Послание Александру Полубенскому (1577) & - & - & - & 1 \\
\hline
\end{tabular}

Существенно, что во многих этих произведениях есмя используется не спорадически, а последовательно, и, значит, является нормой для авторов и переписчиков этой эпохи. При этом, как правило (хотя и не всегда), соблюдается распределение форм 1 ед. и 1 мн. Так, абсолютно четкое противопоставление этих форм, подобное тому, которое наблюдается в Посольских книгах, обнаруживается в «Хожении за три моря» Афанасия Никитина по списку XVI в.: 1 ед. - єсмн (28x) и єсмь (3х), а 1 мн. - только єсмА (19x).

Наблюдение над списками летописей и других гибридных по языку текстов показывает, что различные формы связки 1 мн. принадлежат в них чаще переписчику, чем оригиналу текста. В частности, в поздних летописях (Никоновской, Вологодско-Пермской и т. п.) написание есмя во множестве встречается не только при описании современных летописцу событий, но и в древних частях, относящихся к домонгольскому периоду. Это значит, что употребление той или иной формы определялось орфографической выучкой писца в большей степени, чем влиянием антиграфа. Такая выучка была особенно характерна для писцов Посольского приказа. К концу XVI в. приказные нормы письменного языка широко распространились на всей территории Московской Руси, включая сюда и отдаленные сибирские окраины [Черных 1958: 140]. Авторитет Посольского приказа обеспечивал использование есмя в документах, относящихся к различным сферам деятельности Московского государства, в статусе общерусской нормы.

B XIV-XVII вв. форма есмя проникала и в списки церковнославянских текстов стандартного регистра при их копировании. Например, в московском Евангелии Успенского собора Соболевским отмечено: сЊмА оврадммє ксмл 15 об. [Соболевский 1907: 162]. В списке кормчей XVI в., который использовался Бенешевичем для разночтений с Ефремовской кормчей, написанию Ефремовской кормчей АъАжєни ксмъ соответствует Аъмжьни єсмл [Бенешевич 1906-1907]. Это, по-видимому, является закономерным следствием того, что книгописанием 
в XV-XVI вв. занималось большое количество светских писцов, в том числе служащих Посольского приказа [Костюхина 1974: 14] ${ }^{10}$.

Касаясь вопроса о происхождении формы ксма, А. И. Соболевский писал, что оно «неясно», и продолжал: «но во всяком случае она не может быть объясняема из ксмє, так как переход конечного ударяемого $e$ в $a$ ни в новгородском, ни в московском говорах никогда не был известен (ср. в тех же старых памятниках, где есмя, постоянное сохранение е в есте; естя - по образу есмя - появилось не раньше XV в. (грамота 1503 г. Ак. Юр. 18)» [Соболевский 1907: 162]. Мнение о том, что есмя - «неясная форма», повторяется в других работах, авторы которых, опираясь на материалы А.И. Соболевского, не подвергали сомнению высказанные им соображения [Филин 1972: 466; Ист. гр. 1982: 49 и др.]. Между тем нет никаких оснований считать, что окончание в форме ксма было полноударным, поскольку словоформы настоящего времени глагола быти представляли собой, по выражению А. Вайана, «полуэнклитики» [Вайан 1952: 412], то есть в функции связок имели статус энклитик, хотя в неслужебном значении ('существовать, иметься', 'пребывать, находиться’) вели себя как акцентно самостоятельные [Зализняк 2008: 221]. Поэтому Н.Н. Дурново полагал, что есмя «получилась вследствие фонетического перехода конечного $e$ в $a$ в с л а б о у д а р я е м о м (разрядка наша - A.M.) положении (ср. такое же $а$ в в.-р. меня, тебя, себя)» [Дурново 2000: 306-307]. Что касается указания А.И. Соболевского на отсутствие естя в тех древнейших памятниках, в которых появлялось есмя, то и оно не может быть принято по причине крайней малочисленности соответствующих данных. Наиболее ранняя фиксация естя относится к 1-й половине XV в., и в дальнейшем оно встречается несопоставимо реже, чем есмя ${ }^{11}$ и только в текстах, отражающих аканье. Предположение А. И. Соболевского об аналогическом изменении есте в естя под влиянием есмя не подтверждается и данными псковских говоров, в которых фиксируется форма 3 ед. е́ся (см. ниже), представляющая собой результат фонетического изменения есть > есь в условиях аканья. Связка естя фиксируется приблизительно с того же времени, что и есмя, и ограничено общей с есмя диалектной территорией. Поэтому более вероятно, что их появление было вызвано фонетическими причинами.

Фонетическое объяснение происхождении есмя из есме хорошо согласуется с географией распространения есмя. В новгородских берестяных грамотах, отражающих новгородский диалект «в узком смысле», в 1 мн. зафиксировано только єсмє (6x, см. выше), форма єсма «не встретилась» [ДНД: 139]. В отличие от нормы новгородской бытовой письменности, норма новгородских пергаменных документов формировалась, по-видимому, под влиянием акающей части новгородско-псковских говоров. И это, в свою очередь, объясняет относительную малочисленность примеров отражения на письме диалектного есме, которое поддерживалось

${ }_{10}$ B XVII в. процент светских писцов по датированным рукописям достигает $45 \%$ [Костюхина 1974: 15] — в частности в Посольском приказе — притом что основной работой этих писцов было написание жалованных и иных грамот [Там же: 16].

11 Старорусский подкорпус НКРЯ содержит лишь 151 пример употребления естя. 
произношением только в восточной, окающей части новгородско-псковских говоров, тогда как в условиях аканья оно произносилось и записывалось как есмя. То, как это происходило, наглядно иллюстрируют региональные варианты списков Новгородской I летописи: под 1216 г. в Синодальном списке написано: $а$ кръви не проливаиме. В Комиссионном списке (40 гг. XV в.) - не проливаимя [Зализняк 2007: 41].

Говоря о «слабоударяемом положении», в котором конечное -е в есме переходило в -я, Н. Н. Дурново, по-видимому, имел в виду то, о чем позднее написал А. А. Зализняк [2008: 221]: «Двусложные словоформы вообще склонны к тому, чтобы даже в позициях, где они утрачивают нормальное ударение, все же сохранять некоторое ослабленное ударение (как это происходит, например, с современными ему, его, было)». По-видимому, этот ослабленный характер ударения на двусложной энклитике отражают единичные примеры его обозначения посредством «тупого» ударения на окончании (есмя)) в акцентуированных рукописях XVII в. [Там же: 334].

На возможность древнего ударения е́смя косвенно указывает реликтовое употребление е́стя в современных северных и среднерусских говорах на территории Северо-Запада. Эта словоформа выступает в разных грамматических значениях - 3 мн., 3 ед. и 1 мн.: Е́стя те жъ ме́сныл жьітили устро́ифиы и каро́ф имеют; Прие́хафии-та дачники тожа е́сьтя; Кино́ нынче е́стя?; Дяйстви́тельна, е́ся такая дяревня и др. [Псков. обл. сл, 2: 236-239]; Она естя вепс; Она здешняя естя; Племянник естя полковник; Отец-то еговый естя с-под Костромы; там очень хорошо естя - где магазин; А посконь в конопле естя, как лен; Василий работал естя; Може, естя не пустят (мальчика в кино) - не детское [Кузьмина, Немченко 1968: 150-153]; Да почто он пришоччи естя?; Мы не ездивши естя со своей деревни; Рожь-то естя выжата; Сын естя померии; Мы развевши естя в 34 году; там, наверно, забравии уже естя куры; Жена его естя секретарем; Отеи-то еговый естя с-под Костромы; Здесь красиво естя, воздух чистьй [Кузьмина, Немченко 1971: 181, 191]. В части этих примеров представлено полнозначное употребление глагола есть как акцентно самостоятельной словоформы, которую не всегда удается отличить от связки. Впрочем, строгое разграничение этих употреблений в данном случае не требуется, потому что ударение в полноударных словоформах в любом случае оказывало влияние на ударение в аналогичных связках, и связки не в полной мере утрачивали то ударение, которое имела соответствующая словоформа в качестве полнозначного глагола [Зализняк 2008: 224]. Приведенные выше акцентуированные материалы «Псковского областного словаря» свидетельствуют о том, что ударение в е́стя было на первом слоге. На это указывает и диалектная вариативность форм ecmb, ecb, e, ecmu, есте и естя в одинаковых синтаксических конструкциях, которые свободно чередуются в речи информантов: Гумно на память-то оставши есть; Ребята есть курят; Пасет коров ходит есть; Тамочка есть речка была; Она немножко есть рехнувши; Он померши есть; Я съездила есь в город; Его сестра мне-ка золовка есь; Посконь раньше сохне, с зерном конопля есь; Погибши сын у меня $\boldsymbol{e}$; тут медведь е рывии; как на оборты ходят, так еле живеньки е ставши; Она же здесь вышевши есте (замуж); 
А кромка -у платка ести, вот эта и др. [Кузьмина, Немченко 1971: 181]. В свою очередь, ударение е́стя делает весьма вероятным аналогичное ударение е́смя.

Таким образом, можно полагать, что форма есмя представляет собой отражение на письме акающего произношения есме. Появившись в зоне аканья, она стала письменной нормой Посольского приказа и потому получила распространение на всей территории Московского государства, включая те области, где аканья не было. Помимо ориентации писцов на нормы Посольского приказа, распространению этой формы за пределами акающей зоны могло способствовать то, что она обеспечила противопоставление связок 1 мн. и 1 ед. ч., что было особенно актуально для деловых и официальных документов. Заметим, что естя в таком качестве морфологически не требовалось, т. к. во 2 л. формы единственного числа (еси) и множественного (есте) различались достаточно хорошо, и поэтому тексты, в которых встречается написание естя, ограничиваются территорией аканья.

Форма есмя активно употреблялась в русских документах на протяжении почти четырех веков: самый поздний пример употребления есмя в Старорусском подкорпусе НКРЯ датирован 1668 г. Приблизительно в это время в русском языке в целом завершается процесс вытеснения связок личными местоимениями. В источниках XVIII в. есмя уже не встречается.

Влиянием аканья объясняется и форма есма (из есмо), распространенная в белорусских говорах, которая встречается и в некоторых русских документах. По данным Старорусского корпуса, эта форма, встречается 8 раз в шести документах. В пяти из них она используется в значении 1 мн.:

- Приехали есма въ Трокь [Хождение на Флорентийский собор (14371440)];

- А купили есма те земли [Купчая с отводом старца Гурия Старого, казначея Герасима Ленкова и др. на купленное у Ивана Иванова с. Кувшина-Заболоцкого с. Ангелово в Горетовск. стану Московск. у. (1532.06.10)];

- И от тое реки или есма войском 8 дней полями дикими и дубровами, нъгдъ же и лесами [Андрей Курбский. История о великом князе Московском (1564-1583)];

- бронилися есма имъ [Андрей Курбский. История о великом князе Московском (1564-1583)];

- всяко благодарим Бога, иже есма, за благодатию его, от младости нашей во Священных Писаниях по силе нашей научени [Андрей Курбский. Послание Кодиану Чапличу (1564-1583)].

В трех случаях есма выступает в качестве связки 1 ед.:

- Аки бы рекль: «Не возмогль есма вас мучити» [Андрей Курбский. История о великом князе Московском (1564-1583)];

- Се яз, Юрьи Данилов сын Скрыпеев, дал есма в дом великим страстотерпием христовым Борису и Глебу в манастырь в Муромском уезде в Куземском стану вотчину [Данная Юрия Данилова сына Скрыпеева Борисогл. 
монастырю на половину д. Прудец в Куземском ст. Муромского у. (15751576)];

— И в том есма яз, Иван Суботин сын Чегодаев, дал сю паметь в дом великих страстотерпеи Бориса и Глеба строителю Захарью Ржевскому з братьею за своею рукою [Данная («память») Ивана Субботина сына Чегодаева строителю Борисогл. монастыря Захарию Ржевскому на двор на Кулишках в Москве (1603-1604)].

Сама форма 1 мн. єсмо, которая характерна для ряда славянских языков (средне- и новоболгарского, древнесербского и современного сербского, хорватского, словенского и словацкого языков, а также для украинских говоров), сравнительно редко встречается в старорусских текстах — преимущественно галицко-волынского и западно-русского происхождения. Единичные примеры отмечены в «Александрии» Хронографической редакции (сп. XV в.), в «Истории Иудейской войны» (2x), по одному примеру - в Псковской 2-й и Псковской 3-й летописи по Строевскому списку, в «Сказании о князьях владимирских» и некоторых других ${ }^{12}$. Чаще других авторов єсмо употребляет Андрей Курбский в своих письмах (наряду с єсма и єсма). У Ивана Грозного єсмо встречается только в одном из писем в Послании польскому королю Стефану Баторию 1579 года (4х), где, по-видимому, является стилизацией.

\section{Источники}

Бенешевич 1906-1907 - Бенешевич В.Н. Древне-славянская кормчая XIV титулов без толкований. Т.І. Вып. 1-3. СПб., 1906-1907.

ГВНП 1949 - Грамоты Великого Новгорода и Пскова / Под ред. С.Н. Валка. М.; Л., 1949.

ДНД 2004 - Зализняк А.А. Древненовгородский диалект. 2-е изд., перераб. с учетом материала находок 1995-2003 гг. М., 2004.

Дух. и дог. гр. 1950 - Духовные и договорные грамоты великих и удельных князей XIV-XVI вв. / Подгот. к печ. Л. В. Черепнин. М.; Л., 1950.

НКРЯ - Национальный корпус русского языка (www.ruscorpora.ru).

Псков. обл. сл, 1-27- - Псковский областной словарь с историческими данными. Вып. 1-27-. СПб., 1967-2017-

ПСРЛ II - Полное собрание русских летописей. Т. ІІ. Ипатьевская летопись. M., 1998.

Хрест., 1-2 - Обнорский С. П., Бархударов С.Г. Хрестоматия по истории русского языка. Ч. 1. Изд. 2-е. М., 1952; Ч. 2, вып. 1. М., 1949; Ч. 2, вып. 2. М., 1948.

12 Поэтому неверно утверждение, что такие написания «в памятниках письменности не прослеживаются» [Горшкова, Хабургаев 1982: 292]. В то же время ошибочны все примеры написания -мо в формах глаголов 1 мн., приведенные в [Филин 1972: 467] для иллюстрации употребления этого окончания в древнерусских рукописях: формы пьємо в Изборнике 1073 г. (152а7) и нєв Һроүюмо в 13 Словах Григория Богослова (45a) представляют собой страдательные причастия ср. рода, а форма прьдстүпаємо в Успенском сборнике отсутствует. 


\section{Литература}

Вайан А. Руководство по старославянскому языку. Перевод с франц. В. В. Бородич. М., 1952.

Горшкова К.В., Хабургаев Г.А. Историческая грамматика русского языка. М., 1982.

Граматика на старобългарския език. Фонетика. Морфология. Синтаксис. София, 1993.

Дурново Н. Н. Очерк истории русского языка // Дурново Н. Н. Избранные работы по истории русского языка. М., 2000.

Зализняк А.А. «Слово о полку Игореве»: взгляд лингвиста. Изд. 2-е, доп. М., 2007.

Зализняк А.А. Древнерусские энклитики. М., 2008.

Зализняк A. A. Древнерусское ударение. Общие сведения и словарь. М., 2014.

Иванов В. В. Историческая грамматика русского языка. М., 1990.

Историческая грамматика русского языка. Морфология. Глагол / Под ред. Р. И. Аванесова и В. В. Иванова. М., 1982.

Костюхина Л. М. Книжное письмо в России XVII в. М., 1974.

Кузнеиов П.С. Историческая грамматика русского языка. Морфология. М., 1953.

Кузьмина И. Б., Немченко Е.В. К вопросу об употреблении «есть» в русских говорах // Материалы и исследования по общеславянскому лингвистическому атласу. М., 1968. С. 144-170.

Кузьмина И. Б., Немченко Е. В. Синтаксис причастных форм в русских говорах. M., 1971.

Ралева Ц. Наблюдения върху някои глаголни форми в Изборника от 1073 г. // Език и литература. 2013. № 1-2. С. 119-123.

Селищев А. М. Старославянский язык. Ч. І-II. М., 1951-1952.

Соболевский А. И. Лекции по истории русского языка. Изд. 4-е. М., 1907. (Репринт. переизд.: Соболевский А. И. Труды по истории русского языка. Т. 1. Очерки из истории русского языка. Лекции по истории русского языка / Предисл. и коммент В. Б. Крысько. М., 2004.)

Филин Ф.П. Происхождение русского, украинского и белорусского языков: Историко-диалектологический очерк. М.; Л., 1972.

Черных П. Я. О начале и характере формирования русского национального языка // Научные доклады высшей школы. Филологические науки. 1958. №3. С. 130142.

Kortland F. Toward a reconstruction of the Balto-Slavic verbal system // Lingua. 491979. P. 51-70. 


\section{Alexandr M. Moldovan}

Vinogradov Russian Language Institute of the Russian Academy of Sciences

(Moscow, Russia)

alexandr.moldovan@gmail.com

\section{VARIATION OF THE 1ST PERSON PLURAL FORM OF THE COPULA/ AUXILLIARY IN OLD RUSSIAN TEXTS}

Wide variation in the spelling of the $1^{\text {st }}$ person plural form of the copula verb (jesm jesmy, jesmb, jesmi, jesmo, jesma, jesme, jesm'a) is attested in $11^{\text {th }}$ - to $17^{\text {th }}$-century Old Russian texts. This was due to many factors that were at work in different periods of the history of the Russian written language. Old and Middle Russian corpora provide abundant material for investigating the conditions and mechanisms of operation of these factors. Of special interest is the form jesm' $a$, which is not attested in other Slavic languages, but was extensively used in the $14^{\text {th }}$ to $17^{\text {th }}$ century in Russian business writing and "hybrid" types of literary language. The article argues that the spelling jesm'a reflects the phenomenon of akanje in pronouncing the dialectal form jesm'e. Having emerged in the akanje zone, jesm' $q$ asserted itself as a written norm in the Ambassadorial Prikaz and therefore spread all over the territory of Muscovy, including regions not affected by akanje.

Keywords: Old Russian language, Old Russian written culture, history of the Russian language, historical dialectology.

\section{References}

Chernykh P. Ya. O nachale i kharaktere formirovaniya russkogo natsional'nogo yazyka. Nauchnye doklady vysshey shkoly. Filologicheskie nauki. 1958. №3. S. 130-142.

Durnovo N. N. Ocherk istorii russkogo yazyka. In: Durnovo N. N. Izbrannye raboty po istorii russkogo yazyka. Moscow, 2000.

Filin F.P. Proiskhozhdenie russkogo, ukrainskogo i belorusskogo yazykov: Istorikodialektologicheskiy ocherk. Moscow; Leningrad, 1972.

Gorshkova K.V., Khaburgaev G. A. Istoricheskaya grammatika russkogo yazyka. Moscow, 1982.

Gramatika na starob"lgarskiya ezik. Fonetika. Morfologiya. Sintaksis. Sofiya, 1993.

Istoricheskaya grammatika russkogo yazyka. Morfologiya. Glagol. Pod red. R.I. Avanesova i V. V. Ivanova. Moscow, 1982.

Ivanov V. V. Istoricheskaya grammatika russkogo yazyka. Moscow, 1990.

Kortland F. Toward a reconstruction of the Balto-Slavic verbal system. Lingua. 49. 1979. P. 51-70.

Kostyukhina L. M. Knizhnoe pis'mo v Rossii XVII v. Moscow, 1974.

Kuz'mina I.B., Nemchenko E.V. K voprosu ob upotreblenii «est'»v russkikh govorakh. Materialy i issledovaniya po obshcheslavyanskomu lingvisticheskomu atlasu. Moscow, 1968. S. 144-170. 
Kuz'mina I. B., Nemchenko E. V. Sintaksis prichastnykh form v russkikh govorakh. Moscow, 1971.

Kuznetsov P. S. Istoricheskaya grammatika russkogo yazyka. Morfologiya. Moscow, 1953.

Raleva Ts. Nablyudeniya v"rkhu nyakoi glagolni formi v Izbornika ot 1073 g. Ezik i literatura. 2013. No 1-2. S. 119-123.

Selishchev A. M. Staroslavyanskiy yazyk. Ch. I-II. Moscow, 1951-1952.

Sobolevskiy A.I. Lektsii po istorii russkogo yazyka. Izd. 4-e. Moscow, 1907. (Reprint. pereizd.: Sobolevskiy A.I. Trudy po istorii russkogo yazyka. T. 1. Ocherki iz istorii russkogo yazyka. Lektsii po istorii russkogo yazyka / Predisl. i komment V.B. Krys'ko. Moscow, 2004.)

Vaillant A. Rukovodstvo po staroslavyanskomu yazyku. Perevod s frants. V. V. Borodich. Moscow, 1952.

Zaliznyak A. A. «Slovo o polku Igoreve»: vzglyad lingvista. Izd. 2-e, dop. Moscow, 2007.

Zaliznyak A. A. Drevnerusskie enklitiki. Moscow, 2008.

Zaliznyak A. A. Drevnerusskoe udarenie. Obshchie svedeniya i slovar'. Moscow, 2014. 